\title{
Improving Children's Ability in Knowing Numbers through Triangle Domino Media in PAUD Kenanga
}

\author{
Wirdatul 'Aini \\ Department of Non-Formal Education, \\ Faculty of Education UniversitasNegeri Padang \\ Jl. Prof. Dr. Hamka, UNP Campus Air Tawar, \\ Padang, West Sumatera \\ wirdatul.aini@yahoo.co.id
}

\begin{abstract}
This research was based on the low ability of children to recognize numbers in the Institute for Early Childhood Education (PAUD) Kenanga. This problem is allegedly related to the use of instructional media that is inconsistent with learning materials, as well as teachers have not used instructional media in the classroom. The purpose of this study are to illustrate the improvement of the child's ability in mentioning the sequence of numbers, to know the concept of numbers, and to recognize the symbol of numbers. This research uses classroom action research method. The subjects of this study were children of group A early childhood PAUD Kenanga as many as 15 people. The data collection technique is an observation, and the data collection tool is the observation guideline of data analysis using the percentage formula. The results of this study illustrate the increase in the ability of children in the mention of the sequence of numbers, recognize the concept of numbers, and recognize the symbol of numbers through the medium of domino triangle with high increase results. Suggestions raised through this research so that PAUD educators to be able to use triangle domino media can attract children to improve their ability in recognizing numbers. Besides, PAUD teachers can use varied media in learning activities, so that the learning atmosphere can be conducive so that the learning outcomes of children increases.
\end{abstract}

Keywords--ability; recognize numbe; triangle domino media

\section{INTRODUCTION}

Growth and development is a natural process that takes place in human life, beginning in the womb until the end of life. Growth focuses more on quantitative physical change, while qualitative development means a series of progressive changes as a result of maturity and experience[1].

Humans are never static, since the fetus to death always changes, both physical and psychological abilities. Piaget in [2] explained that the structure was not never static andhas been there since the beginning. In other words, mature organisms always experience progressive change in response to experiential conditions and changes. Growth and development can be influenced by prenatal factors, at birth (prenatal) and after birth (postnatal). In relation to that every child is unique, meaning no two children are exactly alike even though they are identical twins from one egg cell.

From birth to entering primary education is a golden period as well as a critical period in the life stage, which will determine the development of the next child. This period is a good time to lay the groundwork for the development of physical abilities, emotional social language, self-concept, art, morals, and religious values. Thus efforts to develop the full potential of the child should be initiated at an early age so that the child's growth and development are achieved optimally.

Efforts to provide protection to children are regulated in Law No. 23 of 2002 on child protection which states that every child has the right to live, grow, develop and participate fairly according to human dignity, and to be protected from violence and discrimination[3]. One implementation of the right is that every child has the right to receive education and instruction in the context of his personal development and his level of intelligence in accordance with his interests and talents.

The development of children at a certain age includes several aspects, namely physical growth, motor development, speech development, emotional development, social development, play development, creativity development, understanding development, moral development, development of sex development personality. While aspects of early childhood development according to Slamet in Mansur consists of pshycomotoric, intellectual, moral, emotional, social, language, and creativity[2].

Meanwhile, according to Government Regulation No. 27 of 1990 on preschool education early childhood development aspect in broad outline there are two groups namely; basic development groups and habituation development groups. Basic capability development groups include creativity, language, thinking power, skills and body[4]. Creativity aims to form a creative child. The formation of creativity must be integrated in the development of language, thinking, skill and body. Language development aims to enable children to communicate verbally with their social environment. Power of thought aims to enable children to connect knowledge that 
is already known to the knowledge gained. The development of skill aspect aims to make the child skilled to develop gross motor skills as well as fine mootorik which is useful for motor development of children. Physical development aims to develop the physical capability of the child for the health of the child.

Habitual development groups are implemented continuously in everyday activities. Development of this habitation includes aspects: moral, religion, discipline, emotion, and social or social skills. In the implementation of this practice can be done by familiarizing children to pray before doing the activity, thanking if given or helped, asking for forgiveness when making mistakes, say greetings when meeting with others, please help fellow friends, disciplined alternately in or from school.

Man needs education in his life. Education is an effort undertaken so that human beings can develop their potential through the learning process or in other ways known and recognized by the community. Early Childhood Education (PAUD) is a fundamental education that must be provided by the family. Family as the foundation of education in producing the next generation of intelligent, healthy, character and have knowledge that can support the achievement of a better life. In line with that [5] explains that for the future children will certainly make a man who devoted, intelligent, happy and have a good personality and can achieve a successful life later in the day.

The government has developed the potential of children from an early age in preparation for life and to adapt to the environment. To develop various abilities or potentials of children, the development of various abilities or potentials of children, then developed the development aspects of moral development and religious values, physical development, language development, cognitive development, emotional socio-development, art development, and creativity.

Early childhood can be grouped by age level. Earlyage children who are in the age group of 4-5 years. In theory according to Gessel in Susanto the development of cognitive abilities of children, have started to learn mathematics, including children already know the concept of numbers, mention urtan numbers, and recognize the symbol of numbers[6].

Based on the problems that researchers encountered in early childhood early childhood 4-5 years have not been able to recognize the concept of numbers, mention the sequence of numbers, and recognize the symbol of numbers. The early childhood in the PAUD Kenangaare15 person. From 15 new people are able to recognize the sequence of numbers 5 people, 10 people have not been able to recognize the sequence of numbers. Next know the concept of numbers only 2 people, while 13 people have not been able to recognize the concept of numbers. Then the child has not been able to recognize the symbol number as many as 11 people, and only 4 people are able to recognize the symbol of numbers.

In accordance with the problems encountered the researchers suspect the child has not been able to recognize the concept of numbers, mention the sequence of numbers, and recognize the number of symbols such as teachers have not used media that can motivate children to improve the mathematics of children. Teachers have not used a variety of media.

Game tools or media used for learning in early childhood is a factor that is worth noting. According to Piaget in Susanto early childhood thinking ability is at concrete preoperational stage[6]. For children's learning at this time will be very appropriate if the child is confronted with concrete objects they can observe. The use of media or game tools in this period will be able to arouse children's curiosity. The more used the media that is concrete and interesting the growing interest of children to learn mengatahui everything that exists in the environment.

Furthermore, Hurlock explains that learning in early childhood should use more tools / media, as well as examples and concrete objects, a live demonstration packed in play[6]. In this way they indirectly can receive what is taught to them. Furthermore, Hurlock explains that children aged 4-5 years is a child during the game, the child is able to manipulate the symbol symbol object

Based on the problems experienced by early childhood in PAUD Kenanga, where they have not been able to recognize the concept of numbers, mention the numbers, and recognize the symbol of numbers, the researchers find problem solving by doing classroom action research. Objectives to be achieved through this research is the improvement of the ability of the child in terms of: (1) recognizing the concept of billangan, (2) mentioning the order of numbers, and (3) mentioning the number symbol, The achievement of the purpose of this study using triangle domino media.

\section{MATERIAL AND METHOD}

The type of research is quantitative, with the form of research being classroom action. Arikunto (1999) explains that classroom action research is a study done to improve the learning process in the classroom with the intent to find solutions to problems that are experience by students[7]. In this classroom action research the teacher tries to find an inonation in the learning activity, so that the problem faced by the child can be solved. By doing research of class action happened improvement of learning activity by using new media, then result learn of children happened improvement from result of previous learning.

This research was conducted in PAUD Kenanga. The subjects were 15 children of PAUD Kenanga. This study was conducted for two months. Research is done by using planning cycle, action, observation and reflection. Research is done three times a week, and every 2 x 30 minutes. Research is planned 2 cycles. The type of data in this study is data about the ability of children: (1) mention the sequence of numbers, (2) recognize the concept of numbers, and (3) recognize the symbol of numbers. Data collection techniques are observations and data collection tools are guidelines for observation. Data is processed by using the formula percentage. 
Procedure of research according to Kemnis in Arikunto (1999) uses cycles, with four stages: (1) planning is to make lesson plan, design triangle domino media, plan time trial, and implement it, make observation and prepare action plan to be done, 2) take action, is to carry out the learning activities according to the plan work on the first cycle of children divided into two groups[7]. Each group performs the game using triangle domino media. One by one the children are asked to pick up a colorfully designed triangular medium, and try counting from the smallest to the big one or from one to ten. The next step the children start selecting the number symbols taken that match the number of numbers. Then the children are able to assess the number of objects taken in accordance with the numbers that the teacher exhibited. Steps (3) Observation of children being assisted by other teachers through assessment of the child's activities in the operational number, and (4) reflecting is in order to assess the learning outcomes obtained by the child.

In the first cycle of this study the learning outcomes of children has not happened a significant increase. Therefore proceed to the second cycle, with the same work procedure as the first cycle. The difference between the first cycle with the second is; in the first cycle the child performs the operational number in the group, then in the second cycle the children perform their own operational numbers. The observation results indicate a significant increase in the ability of the child: (a) to know the sequence of numbers, (2) to recognize the concept of numbers, and (3) to recognize the number symbols.

\section{RESULTS AND DISCUSSION}

Based on the results of the study of early childhood youth in the first cycle with six meetings in terms of the ability of children (1) to know the sequence of numbers at the first meeting by $43 \%$, the second meeting by $50 \%$, and the third meeting $60 \%$, (2) the number at the first meeting is $20 \%$, the second meeting is $26.6 \%$, and the third meeting is $36.6 \%$. then, (3) the number of first numbers at the first meeting is $13 \%$, the second meeting is $24 \%$, and the third meeting is 31 $\%$.
From the results of the first cycle of research has not been an increase in learning outcomes of children in terms of number sequence, understanding concept of numbers and recognize the symbol of numbers. Therefore, the study continued on the second cycle. Research planning is similar to the first cycle, which distinguishes it in the first cycle of children learning in groups and in the second cycle children learn by themselves. In this second cycle the implementation is the same as the first cycle, with learning activities 3 times a week. The media used is more varied again with many colors, so it is more interesting for children to do activities in learning

The results of the second cycle study illustrate the ability of the child in terms of; (1) understanding sequence number, the first meeting of $70 \%$, the second meeting of $80 \%$, and the third meeting of $90 \%$, then (2) recognize the concept of numbers, at the first meeting of $46.7 \%$, the second meeting of $63.4 \%$, and third meeting of $73.6 \%$, then (3) recognize the number symbols at the first meeting by $40 \%$, the second meeting $53 \%$, and the third meeting of $66.7 \%$.

Further described the conditions between cycles 1 and 2 by using triangular domino media can improve the ability of children in; (1) know the sequence of initial condition number $43 \%$, first cycle $60 \%$ second cycle $90 \%$. The difference of initial condition with cycle 1 is $16,7 \%$, difference of initial condition with cycle 2 is $46,7 \%$, and difference of cycle 1 with cycle 2 is $30 \%$. Furthermore, (2) the ability to recognize the concept of initial condition number $13,3 \%$, first cycle $36,3 \%$, second cycle $73,6 \%$, and difference of initial condition with cycle 1 is $23 \%$, difference of initial condition with cycle 2 is $60 \%$ and the difference of cycle one with cycle 2 is $37.3 \%$. Then (3) the child's ability to recognize the initial condition number $6.7 \%$, the first cycle is $31 \%$, cycle 2 is $66.7 \%$. The difference of initial condition with cycle 1 is $24.3 \%$, the difference of initial condition with cycle 2 is $35.7 \%$, and the difference of cycle 1 with cycle 2 is $11.4 \%$. The average initial condition was $21.1 \%$, cycle 1 was $42.5 \%$, cycle 2 , was $76.8 \%$, the difference of initial condition with cycle 1 was $21.3 \%$, the difference of initial condition with cycle 2 was $47.5 \%$, and the difference of cycle 1 with cycle 2 is $26.4 \%$. For more details can be described in the following table:

Table 1.Recapitulation of Improving Children's Ability in Knowing Numbers Before and after Cycle 1 and 2

\begin{tabular}{|c|c|c|c|c|c|c|c|}
\hline Num. & Aspects observed & $\begin{array}{l}\text { Initial } \\
\text { condi- } \\
\text { tions }\end{array}$ & Cycle 1 & Cycle 2 & $\begin{array}{c}\text { Difference of } \\
\text { initial } \\
\text { condition } \\
\text { with cycle } 1 \\
\end{array}$ & $\begin{array}{c}\text { Difference of } \\
\text { initial } \\
\text { condition } \\
\text { with cycle } 1 \\
\end{array}$ & $\begin{array}{l}\text { Difference } \\
\text { cycle } 1 \text { with } \\
\text { cycle } 2\end{array}$ \\
\hline 1 & Mention the order of numbers & 43,3 & 60 & 90 & 16,7 & 46,7 & 30 \\
\hline 2 & Knowing the concept of numbers & 13,3 & 36,3 & 73,6 & 23 & 60 & 37,3 \\
\hline \multirow[t]{3}{*}{3} & Knowing the number symbol & 6,7 & 31 & 66,7 & 24,3 & 35,7 & 11,4 \\
\hline & Total & 63,4 & 127,6 & 230,3 & 64 & 142,4 & 79,1 \\
\hline & Averages & 21,1 & 42,5 & 76,8 & 21,3 & 47,5 & 26,4 \\
\hline
\end{tabular}


Based on table 1 can be seen picture of improvement of ability of children to know number with indicator; mention the sequence of numbers, recognize the concept of numbers, and recognize the symbol of numbers. From table 1 illustrated there is an increase in the understanding of children in terms of mentioning the sequence of numbers from the initial conditions to cycle 1 , cycle 2 , the initial condition difference with cycle 1, the difference of initial conditions with cycle 2 . Similarly from table 1 illustrated there is an increase in the ability of children to know the concept of number from initial condition to cycle 1 , cycle 2 , difference of initial condition with cycle 1 , difference of initial condition with cycle 2 , and seslih cycle 1 with cycle 2. Furthermore from table 1 illustrates the improvement of the ability of the child to recognize the number symbol there is an increase from the initial condition to the cycle 1 , cycle 2 , difference of initial condition with cycle 1 , difference of initial condition with cycle 2 , and difference of cycle one with cycle 2[8].

From the results of research conducted there is an increase of the child's ability to know the sequence of numbers by using triangle domino media designed by the teacher. In theory according to Gessel children aged 4-5 years the development of cognitive abilities of children has started to direct, children have started to learn mathematics, including children already know the concept of numbers, mention urtan numbers, and recognize the symbol of numbers[6]. From Susanto's opinion the task of the teacher provides motivation to the child so that the child will be more interested in learning math better.

Furthermore, it can be argued that children at the age of 35 years according to Montesori in Susanto (2011), that at this time is also called the sensitive period, which has significance for the development of every child. Sensitive period is where the child at this time will quickly understand everything that causes stimulation of him. The ability to respond to everything that comes from the environment is very high. Children want to know everything that is in their environment. By karaena that at this time the educators should be able to facilitate children with various kinds of toys, bringing children to know the surrounding world.

The development of thinking ability of children at this time grow quickly, especially with the availability of facilities, the media prepared by teachers in learning activities. Media is a tool or as an intermediary for teachers to help the learning process activities in the classroom. From the research results obtained that the triangle domino media can improve the learning outcomes of children know the number. This is in line with the opinion Sriningsih (2008), that children will understand the concept of numbers through experience working and playing directly with concrete objects. The concrete objects that children can operate will provide a real experience to the child and the child will quickly respond to something he immediately observed. Furthermore at this time disebt also concrete operational. Objects that are observed, objects that children play will very quickly develop their thinking ability.

Furthermore, the ability to recognize the concept of the number of children aged 4-5 years. At this stage the child is able to recognize the concept of numbers 1-10. At this stage also called the quantity stage of research results of the ability of children to recognize the concept of numbers with a high percentage after using triangle domino media. Copley argues that children aged 4-5 years have the ability quantity. the ability of quantity is the ability of the child to know the number of objects in front of him degan way of counting in sequence of an object. For example children count the number of fingers $1,2,3,4$, and 5 .

The child can achieve the development of the ability to understand the concept of numbers through real experience. From the play activities using the domino media triangle children gain experience to understand the concept of numbers. The triangle domino medium mediates the children's understanding of the nature of abstract numbers into concrete. According to Sri Ningsihunderstanding of children in understanding the concept of numbers through real experience, where children experience playing and working with concrete objects[9].

In line with that Hurlock in susanto explains for early childhood learning should be more use of tools / media, as well as examples and concrete objects, direct demonstrations are packaged in the form of play[6]. In this way they indirectly can receive what is taught to them. Hurlock describes 4-5 year olds are children during the game, children can manipulate symbols of object.

Using of the triangle domino media in accordance with the theme of learning to know the number. The media consists of images that can be used to mention numbers, recognize the concept of numbers, and recognize the symbols of numbers. With the pictures on the triangle domino media, will grow the child's curiosity to the object observed.

Then at the age of 4-5 years research findings illustrate that early childhood can improve its ability to recognize the symbol of numbers by using triangle domino media. The child is able to name the sequence of numbers, then match the number symbol.

At this stage the child can already be familiarized to remember symbols or symbols of numbers, and the child is also able to write the symbol of numbers[9]. Coupleyexplains that children aged 4-5 years at the stage of recognizing and writing (recognizing and writing numbers), is a child's ability to understand the symbols $1,2,3,4,5,6,7,8,9,10$, dqan remember the symbol of each-each symbol[10].

Children can pay attention to the symbols of numbers written on triangle domino media when they was playing. Triangle domino media is designed so that children can recognize the symbol of numbers, sort the numbers, and count them. Triangle domino media can be observed by children and will cause the child to know the memory of the number in the media. The child enthusiastically explains the numbers emblem they see in the triangle domino media. 


\section{CONCLUSION}

Based on the research findings and discussions that have been described, it can be concluded as follows: (1) the ability of children in mentioning the sequence of numbers increased very high, (2) the ability of children in recognizing the concept of numbers increased very high, (3) the ability of children in recognizing the number symbol increased very high. Increasing the ability of children to know the number in paud because in the learning activities of teachers using triangle domino media. Media designed by teachers based on learning objectives to be achieved, seems more successful in improving the ability of children to know the number.

Through this research the researcher suggested that paud teacher use media in class, because madia can foster the spirit of children to learn. Furthermore paud teacher can use triangle domino media to improve the ability of children to know the number. Besides, teachers can also use specially designed media.

\section{References}

[1] K. H. Dewantara, Bagian Pertama Pendidikan. Yogyakarta: Majlis Luhur Persatuan Taman Siswa, 1977.

[2] Mansur, Pendidikan Anak Usia Dini dalam Islam. Yogyakarta: Pustaka Pelajar, 2005.

[3] Undang-Undang Nomor 23 Tahun 2002 tentang Perlindungan Anak. 2002.

[4] Peraturan Pemerintah Nomor 27 tahun 1990. Tentang Pendidikan Anak Prasekolah. 1990.

[5] Santoso, Pendidikan Anak Usia Dini. Jakarta: Citra Pendidikan, 2011

[6] A. Susanto, Perkembangan Anak Usia Dini Pengantar dalam Berbagai Aspeknya. Jakarta: Prenada Media Group, 2011.

[7] S. Arikunto, Dasar-dasar Evaluasi Pendidikan. Jakarta: Tarsito, 1999.

[8] Khomsatun, Pembelajaran Menegnal Bilangan1-10 Melalui Investasi Bermain Tata Angka PLB. Bandung: PLB, 2010.

[9] Sriningsih, Pembelajaran Matematika Terpadu untuk Anak Usia Dini. Bandung: Pustaka Sebelas, 2008.

[10] Couplay, The Yaoung Child And Mathematics. National Associacion for the Education of Young Children, 2001. 